\title{
ENTRE BRINCADEIRAS, PERFÍDIA E SUFOCAMENTO: INFÂNCIAS NEGRAS NA (PÓS-)COLONIALIDADE EM NARRATIVAS DO CARIBE FRANCÓFONO E DO BRASIL ${ }^{1}$
}

Vanessa Massoni Da Rocha

Resumo: Este artigo se propõe a estudar os retratos romanescos da infância em quatro obras afrodiaspóricas das Américas e, para tal, promove interfaces entre duas narrativas do Caribe de expressão francesa e duas obras brasileiras. No intuito de cartografar a infância de crianças negras, ao longo do período colonial, contempla-se os romances La mulâtresse Solitude (1972), de André Schwarz-Bart, e Água de barrela (2016), da carioca Eliana Alvez Cruz, que expõem a condição de "brinquedo humano" (CRUZ, 2018a, p. 87). Rebaixadas ao mais vil dos lugares, as crianças-brinquedos ilustram a "coisificação" (CÉSAIRE, 2020, p. 24) ou a "animalização" (KILOMBA, 2019, p. 79), estados nos quais ocorrem a destituição da humanidade dos pequenos. Centrados na pós-colonização, os livros Un cœur à rire et à pleurer - contes vrais de mon enfance (1999), da guadalupense Maryse Condé, e Ponciá Vicêncio (2006), da mineira Conceição Evaristo, denunciam que "as antigas práticas coloniais deixaram resquícios" (ALMEIDA, 2019, p. 125) que continuam a operar na contemporaneidade, cindindo de maneira profunda as relações, a engrenagem social e a história da humanidade.

Palavras-chave: Infância. "Brinquedo humano". Literaturas caribenhas. Literatura afro-brasileira. Literatura comparada.

Abstract: This article proposes to study the romances portraits of childhood in four aphrodiasporic works from the Americas and, for that, it promotes interfaces between two French-speaking Caribbean narratives and two Brazilian works. In order to map the childhood of black children, throughout the colonial period, the novels $A$ Woman Named Solitude (2011), by André Schwarz-Bart, and Água de barrela (2016), by Eliana Alves Cruz, feature the condition of "human toy" (CRUZ, 2018, p. 87). Downgraded to the most vile of places, toy children illustrate "objectification" (CÉSAIRE, 2020, p. 24) or "animalization"

1 Título em língua estrangeira: "Between play, performance and suffocation: black children in (post-) coloniality in narratives from the francophonic Caribbean and Brazil". 
(KILOMBA, 2019, p. 79), states in which the destitution of the humanity of small children occurs. Centered on post-colonization, the books Tales from the heart: true stories from my Childhood (2001), by Maryse Condé, and Ponciá Vicencio (2006), by Conceição Evaristo, denounce that "the old colonial practices left remnants" (ALMEIDA, 2019, p. 125) that continue to operate in the contemporary world, deeply dividing the relationships, the social gear and the history of humanity.

Keywords: Childhood. "Human toy". Caribbean literature. Afro-Brazilian literature. Comparative literature.

Os poetas declaram que, sejam quais forem as circunstâncias, uma criança não pode nascer fora da infância; que a infância é o sal de terra, o solo de nosso solo, o sangue de todos os sangues ${ }^{2}$ (CHAMOISEAU, 2017, p 135)

O escritor martinicano Patrick Chamoiseau propõe nas páginas finais da obra Frères migrants [Irmãos migrantes] (2017) uma "Declaração dos poetas", na qual elenca dezessete súmulas para nossos tempos. Na décimasegunda, define a infância como o período áureo das crianças, definindo-o como a terra, o solo, o sangue, a "respiração do vento" (CHAMOISEAU, 2017, p. 135) e o "raio fértil" (CHAMOISEAU, 2017, p. 135). De maneira poética e lúdica, a infância é associada a fenômenos naturais, a astros e a elementos corporais e da superfície terrestre. Nestes termos, a infância, pelos olhos do poeta, mobiliza a vida em todo seu esplendor, como demonstra o trecho que figura na epígrafe deste artigo. Em outras palavras,

2 São de minha autoria a tradução do francês para o português de obras literárias e teóricas referenciadas em francês. 
para Chamoiseau, a infância encarna três instâncias fundamentais: o chão, o céu e o corpo. É o solo por onde se caminha, se equilibra e onde se cultiva o alimento. É o céu que ilumina, controla o tempo, determina dias e noites e rega as plantações. A infância também diz respeito ao sangue que pulsa, líquido que alimenta, faz respirar, circula por todo o nosso organismo. Parece que nada escapa à infância, época intensa de descobrires e sentires, definida através da boniteza de suas potencialidades.

Em seu inciso de estreia, a "Declaração dos poetas" preconiza que "nem órfão, nem sem efeitos, nenhuma dor tem fronteiras!" (CHAMOISEAU, 2017, p. 131). E neste ponto se convergem as duas temáticas centrais deste estudo: articular o período da infância de negros e negras às dores que nela incidem e que insistem em reverberar na vida adulta. Para tal, contemplaremos narrativas afrodiaspóricas tanto do Caribe de expressão francesa, através de autores da ilha da Martinica e do arquipélago de Guadalupe, quanto da literatura afro-brasileira, a partir de romances contemporâneos da mineira Conceição Evaristo e da carioca Eliana Alves Cruz. As Américas, definidas de maneira precisa pela escritora moçambicana Paulina Chiziane como "filha[s] da África" (2017, p. 88), foram palco da empreitada colonial, 
da escravização, da exploração da mão de obra de seres originários e de negros, da "depossessão" do corpo, da imposição religiosa, enfim, da "barbárie suprema" (CÉSAIRE, 2020, p. 18) imperialista-capitalista escamoteada de missão civilizatória (CÉSAIRE, 2020, p. 11).

Assim, a experiência colonial abre sulcos identitários, refaz geografias, impõe o império da "desconfiança universal" (SCHWARZ-BART, 2005, p. 34) e institui dicotomias que cantonam, em um lado, brancos europeus e, em outro, negros em diáspora e seus descendentes, cindindo de maneira profunda as relações, a engrenagem social e a história da humanidade. Neste contexto, o presente artigo busca cartografar a representação da infância em dois momentos: o primeiro lança o holofote sobre a vivência de crianças brancas e negras durante o período colonial, que se estendeu nas ilhas caribenhas de 1635, quando da chegada do colonizador francês, até 1946, ano da departamentalização. No Brasil, a colonização se inaugura em 1532 com a criação do primeiro núcleo de povoamento, a Vila de São Vicente, e se encerra a independência do Brasil, outorgada em 7 de setembro de 1882. O segundo momento, ancorado na contemporaneidade, enseja observar como as feridas da experiência colonial permanecem expostas em 
textos cujos autores revivem e ficcionalizam traumas que marcaram tanto sua infância quanto seus imaginários.

O livro Frères migrants toma como ponto de partida a crise imigratória e a tragédia dos refugiados no Oriente Médio, para os quais a morte por afogamento do menino sírio-curdo Aylan Kurdi, de três anos, durante a viagem clandestina da Turquia para a Grécia, se tornou um fatídico símbolo. A foto do corpo do menino com o rosto fincado na areia na praia de Bodrum, na Turquia, ganhou manchetes, chocou o mundo e trouxe à tona uma preocupante realidade com relação à infância: nem sempre ela se apresenta como metáfora positiva de chão, céu e corpo. Lamentavelmente, há aqueles sob os quais o chão se torna um mar revolto que naufraga embarcações; há outros sobre os quais os céus estão tomados por tormentas. Existem, ainda, crianças para as quais o corpo se torna sinônimo de catástrofe. E é imprescindível perceber aqueles que acumulam infortúnios e perecem, de maneira atroz, diante de céus, chãos e corpos mortíferos.

Patrick Chamoiseau faz alusão à "foto do pequeno Aylan" (CHAMOISEAU, 2017, p. 106) em seu texto e nos convida, diante da tragédia, a "pensar naquelas crianças que viveram, que ainda estão passando por isso. Elas conheceram a violência do mundo" (CHAMOISEAU, 2017, p. 
117). Nesta ótica, se esclarece a presença contundente da infância na "Declaração dos poetas", espécie de cartilha dos direitos dos seres humanos, nos dias de hoje. A fotografia do menino de três anos escancara infâncias brutalmente interrompidas e desvela violências quotidianas que, além de não pouparem os miúdos, os lançam em aventuras dramáticas que acentuam suas vulnerabilidades em um mundo feroz e indiferente.

O drama de Aylan se sobrepõe a revezes muito mais longínquos de infâncias nas Américas. Revezes que, ao contrário do que ocorreu com o menino, não atingiram proporções midiáticas no globo, nem tampouco despertaram comoção, raiva, tristeza e compaixão em toda a parte. $\mathrm{Na}$ contramão de dores compartilhadas, há, ainda, muitas dores silenciadas, invisibilizadas, da qual não supomos a grandeza nem conhecemos seus desdobramentos. No intuito de dar a ver estas dores da infância, os imaginários literários se mostram profícuos campos de representações.

No âmbito brasileiro, o poeta Éle Semog discorre, em entrevista concedida ao professor e pesquisador André Uzêda, sobre a ausência da representativa dos negros nas produções nacionais. Em dado momento, pontua: "Eu precisava beijar a boca da mulher negra, eu precisava achar 
o meu nariz bonito, eu precisava ver que o meu cabelo vai na direção do sol, eu precisava amar a minha criança - e nessa literatura em que eu fui formado não tem isso" (CRUZ, 2018b, p. 7, grifo nosso). Diante deste cenário, ele defende que "o papel da literatura negra era o de interromper com essa situação" (CRUZ, 2018b, p. 7).

Na esfera antilhana, Patrick Chamoiseau costura uma estreita relação entre a infância e os poetas:

Não abandonamos a infância, nós a guardamos bem no fundo de nós. Nós não nos desprendemos dela, nós a recalcamos. Não é um processo de melhoria que leva ao adulto, mas a lenta sedimentação de uma crosta em torno de um estado sensível que sempre estabelecerá o princípio do que nós somos. Não saímos da infância, passamos a acreditar na realidade, o que se diz ser o real. [...] $O$ real (que a infância percebe em ampla proximidade) é uma explosão complexa, desconfortável, de possíveis e de impossíveis. Crescer significa não ter mais força para assumir a percepção disso. Ou é erguer entre essa percepção e você mesmo o escudo de um invólucro mental. O poeta por isso - não cresce nunca ou muito pouco. (CHAMOISEAU, 2015, p. 93-94)

Assim, Semog e Chamoiseau jogam luzes sobre a promissora relação entre escrita e infância. Para o primeiro, a literatura permite melhor ver e acolher as crianças, 
além de criar referências para as novas gerações. Para o martinicano, a infância permite uma melhor percepção da realidade, o que leva os poetas a manterem acesas as chamas desta fase. Nestes termos, proponho o início de um brevíssimo panorama a partir do romance La mulâtresse Solitude (1972), de André Schwarz-Bart. A despeito de ter tido diversas traduções, a obra ainda não possui sua versão brasileira. Consultarei, para fins de citação, a edição portuguesa A mulata Solidão (2005), com tradução de Maria João Branco.

André Schwarz-Bart, autor francês, de origem polonesajudaica, retorna à cena literária em 1972, após ter sido laureado em 1959 com o prestigioso prêmio Goncourt, por seu romance de estreia $O$ último dos justos. Marido da escritora guadalupense Simone Schwarz-Bart, André viu tanto da obra em questão quanto do ambicioso projeto do Ciclo Antilhano receber um acolhimento mitigado. O Ciclo Antilhano configura a concepção de uma saga literária escrita pelo casal Schwarz-Bart, saga que ensejava repertoriar a história caribenha, entre 1760 e 1953, a partir dos passos da líder antiescravagista Solitude, de seus ancestrais e de seus descendentes. Em uma época de "críticos que identificam um autor por nacionalidade, idioma ou sua origem" (GYSSELS, 
2008 , p. 150-151), a branquitude e a origem europeia de André foram vistos como empecilhos e como condições de deslegitimação para a empreitada literária em torno de uma escravizada que se tornou um vulto das resistências guadalupense e caribenha. Apesar de continuar escrevendo com regularidade, o autor faleceu em 2006 sem ter publicado novas obras.

Considerada um "etno-romance" (GYSSELS, 2019, p. 3), a narrativa La mulâtresse Solitude acolhe, de maneira emblemática, a personagem histórica Solitude/Solidão, escravizada que se torna líder da resistência quando Napoleão Bonaparte decide revogar a abolição da escravatura e restabelecer a escravização no arquipélago de Guadalupe, em 1802. Capturada em combate contra o exército francês, ela é presa e levada à forca, em praça pública, aos 30 anos de idade, um dia após ter dado à luz uma menina. Tratase de uma epopeia biográfica organizada em duas partes, sendo a segunda delas consagrada à Solitude e a primeira dedicada à Bayangumay, escravizada africana violentada por um marinheiro branco no barco negreiro entre o Senegal e o arquipélago de Guadalupe. Deste estupro nascerá Rosalie, conhecida como Duas-Almas, que assumirá o nome de Solitude, numa auto-cerimônia de batismo (SCHWARZ- 
BART, 2005, p. 77). A menina mestiça será arrematada por um fazendeiro, trocará de donos algumas vezes e passará por agruras antes de usufruir da liberdade tardiamente conquistada, liberdade esta que o Império francês busca usurpar em 1802.

Antes de passar à análise de trechos do romance e de flagrar Solitude enredada nas ciladas de uma infância de provações, algumas ponderações emergem ao primeiro plano. No que tange à infância de meninas e meninos escravizados durante o período colonial, que se realizou ao longo dos séculos XVI, XVII e XVIII nas Américas, é preciso atentar para o fato de que "uma criança em cada quatro morre em seu primeiro ano" (MEMMI, 2007, p. 71) e que

não existe contabilidade que meça o horror do tráfico de escravos e a abominação da escravidão. Os cadernos dos navegadores, traficados, não testemunham da extensão das invasões, do sofrimento de crianças exaustas e assustadas, da angústia desesperada das mulheres, da revolta oprimida dos homens. (TAUBIRA, 2015, p. 171, grifo nosso)

Christiane Taubira, intelectual nascida na Guiana Francesa, exerceu cargos políticos de deputada e ministra da justiça e se destacou por capitanear o projeto de lei que considerou o tráfico negreiro um crime humanitário no parlamento francês, em 2001. Suas análises acerca 
da escravização evidenciam o silenciamento das vozes de crianças, mulheres e homens submetidos aos flagelos coloniais e o controle das narrativas por parte de seus agentes. Em sua enumeração, a autora enfatiza crianças exaustas e assustadas que, é preciso acrescentar, pouco ou nada compreendiam do vilipêndio diário ao qual estavam expostas. Não me proponho a mensurar a dor das crianças tampouco de compará-la com demais dores, afinal, como preconiza a filósofa brasileira Vila Piedade, "não há dor maior ou menor. Dor não se mede. É de quem sente. Há dor. Dor dói e ponto" (PIEDADE, 2017, p. 18). Parece-me, todavia, relevante um exercício intelectual que se alicerce nas malhas dos imaginários literários, a fim de destacar os infortúnios infantis e a maneira como os pequenos transitavam entre inocência, perfídia e sufocamento durante a "brutal investida" (ALMEIDA, 2019, p. 202) da empreitada colonial.

Numerosos são os relatos históricos sobre suicídios de grávidas escravizadas e sobre os abortos que buscavam não fazer prosperar o horror colonial e escravagista. As crianças eram majoritariamente filhas de estupros e seu nascimento potencializava o sofrimento das mães, privadas de amamentar seus rebentos e obrigadas e vê-los serem 
comercializados e apartados de si para sempre. De fato, a escravização realizou um "ato de depossessão do ventre das mulheres" (VERGÈS, 2017, p. 98) e a maternidade, neste contexto, se revelava uma opressão sobre o corpo e o destino da mulher, uma maneira de curvá-la à ordem imperialista, ordem atrelada à "procriação" (PIEDADE, 2017, p. 30) compulsória e deliberadamente descomprometida com a ideia de que os negros pudessem compor uma família. Patrick Chamoiseau reitera os laços complexos entre a mãe e seus filhos no período colonial ao defender que "sua sobrevivência é a criança. Se ela não a sufocou em sua barriga, ela luta para tirá-la dessa condição. O imaginário das mulheres se projeta na criança a ser salva: elas se reumanizam assim" (CHAMOISEAU, 2011, p. 166). Nesta lógica, a cada criança não salva, as mães mergulham mais profundamente na desumanização; cada filho arrancado dos braços acentua a espiral de mazelas em suas melancólicas sobrevivências.

A propósito do nascimento e da primeira infância de Rosalie/Solitude, o narrador do romance schwarz-bartiano revela que

infelizmente, não foi possível separar a pequena Rosalie de sua mãe, pois apanhava logo infecções na boca, purulências nos olhos e na barriga [...] Os negros diziam que o cordão umbilical tinha sido mal cortado, o 
que era irrevogável. O Sr. Mortier ${ }^{3}$ resignouse, estabeleceu uma forte vigilância receando que a negra maltratasse a filha, como acontecia frequentemente com crianças que eram fruto da Pariade. (2005, p. 65)

A Pariade consistia no estupro da mulher escravizada ainda no navio negreiro, prática estimulada pelos atravessadores, no intuito de assegurar melhor preço de venda nas feiras e leilões nas cidades onde aportavam. Uma mulher grávida se tornava, forçosamente, muito mais rentável do que as demais. O trecho do romance demonstra a frustração do proprietário em ver adiado o projeto de separação de mãe e filha. De fato, no romance, a mãe só pôde prolongar a convivência com a filha por conta das reiteradas doenças da pequena. Em outras condições, a mãe estaria relegada, há tempos, ao posto de parideira impedida de escolher o nome, de cuidar, de amamentar, de experienciar o puerpério e a maternidade em suas plenitudes. Além disto, a associação empreendida entre o cordão umbilical não cortado e as enfermidades do bebê acentua as condições precárias em que se desenvolve a gestação e em que ocorreu o parto. A se observar, igualmente, o medo do dono diante da possibilidade de a mãe ceifar a criança das opressões que Ihe estavam destinadas, optando,

3 A se levar em conta o sobrenome do proprietário, Mortier, que significa em francês, dentre outras acepções, morteiro. O caráter explosivo - mortífero, até - de sua personalidade e de seu papel social na dinâmica colonialista se vê ressaltado neste jogo ficcional. Nestes termos, seu sobrenome revela muito de seu portador e antecipa suas maldades. 
em um ato desenfreado e desesperado, por abreviar sua vida. Como se vê, as violências se mostram de toda ordem e a criança já nasce sob a ótica da mazela, do abandono, da falta e do desleixo, o que explica a alta taxa de mortalidade tanto no nascimento quanto nos anos iniciais de vida, como já foi mencionado.

Superadas as primeiras - e contundentes - provações, as crianças exerciam, desde a mais tenra idade, funções nas fazendas, sendo-lhes negado o direito ao sonho, às brincadeiras e à inocência. "As crianças não trabalham para brincar, trabalham duro" (TAUBIRA, 2015, p. 9); a infância dos negros, no período colonial, era o despertar de uma vida amarga, austera e de identidades vilipendiadas. Ao estudar, ao longo de sua tese de doutorado, crianças cativas e ingênuas nas propriedades da cidade mineira de Mariana, no Brasil, entre 1850 e 1888, a historiadora Heloisa Teixeira afirma que

além da reprodução natural, da compra de crianças escravas e da manutenção dos ingênuos em suas propriedades, como prestadores de serviços, os senhores marianenses usaram de outros meios, a fim de assegurar ou ampliar o patrimônio cativo na segunda metade do século XIX: escravizavam crianças libertas, disputavam a posse de crianças escravas, omitiam a condição de livre para filhos de escravas 
nascidos após 1871 e, até mesmo, furtavam crianças. Outro meio de assegurar a mãode-obra infantil foi através das alforrias condicionais. A maioria das crianças cativas conseguia o título de liberdade mediante a prestação de serviços por determinado período, que podia ser estipulado em alguns anos ou até a morte do proprietário. (TEIXEIRA, 2010, p. 89-90)

Dados apresentados por Heloisa Teixeira, em sua pesquisa na área de História econômica, permitem compreender que, na cidade de Mariana, nos trinta últimos anos do período colonial no Brasil, as crianças eram consideradas aptas para iniciar suas atividades de trabalho a partir dos 7 anos de idade. Ao observar as matrículas das fazendas, ela aponta que

normalmente os campos "aptidão para o trabalho" e "profissão" eram preenchidos para as crianças com menos de sete anos com as designações de "nenhuma", "nada", "não consta", "para o futuro". Os cativos com idade variando entre sete e doze anos receberam qualificações como "aprendiz", "princípio de profissão", "ajudante". Já a descrição da profissão ou a "aptidão para qualquer trabalho" correspondeu, quase sempre, aos escravos com idades entre treze e quatorze anos. (TEIXEIRA, 2010, p. 90)

Neste cenário de espoliação, não se pode perder de vista que "o colonizado não se sente nem responsável nem 
culpado nem cético; simplesmente fica fora do jogo. De nenhuma maneira é sujeito da história; é claro que sofre o peso dela, com frequência mais cruelmente do que os outros, mas sempre como objeto" (MEMMI, 2007, p. 134). Aprofundando a percepção da "coisificação" (CÉSAIRE, 2020, p. 24) dos colonizados, Taubira salienta o fato de que tanto as crianças quanto os adultos, neste contexto usurpatório, passarem a ser 'móveis, 'gado' e 'escravos': "Homens, mulheres, crianças? Móveis, de acordo com o Código Negro. Gado, de acordo com o gerente. Escravos à mercê de acordo com o proprietário" (TAUBIRA, 2015, p. 10). As nomenclaturas postas em cena pela intelectual guianense explicitam a ausência de infância, desta infância nos termos replicados pelo senso comum, segundo o qual a infância consiste em período de desenvolvimento pleno das habilidades da criança. Assim, as crianças negras no âmbito colonial se afastam sobremaneira das primeiras acepções de infância formuladas por Patrick Chamoiseau em sua "Declaração dos poetas"; elas se aproximam dos revezes impingidos a crianças como Aylan, cuja infância se vê envolta em tormentas e tragédias reiteradas.

A estreia de Rosalie/Solitude como escravizada na casa do Sr. Mortier não tarda a fazê-la descobrir seu papel social 
de objeto de companhia, esvaziado de qualquer resquício de humanidade:

O Sr. Mortier decidiu oferecer a criança à sua própria filha, Xavière, que tinha a mesma idade de Rosalie, pois a sua história comovê-la-ia o suficiente para fazer dela uma cocotte. Xavière tinha uma naturalidade doce, suave, não seria arriscado confiar-lhe um objecto tão encantador. O único aborrecimento era o incómodo gaguejar de Rosalie, que a tinha tomado logo após a partida da mãe. [...] O Sr Mortier mandou lancetar o lado posterior da língua de Rosalie, tal como se faz o véu dos pássaros. [...] Um fiozinho de sangue escorreu dos cantos amuados da sua boca, semelhante à boca de uma solha. Puseram-lhe arnica e ela gaguejou como anteriormente. (SCHWARZ-BART, 2005, p. 66 , grifo do autor)

Nesta cena, se descortina uma função inquietante das crianças negras escravizadas: a de servirem de objeto, de bonecos e de capachos pronto a cumprir ordens de crianças brancas. E, desta maneira, se acentua a clivagem entre a infância de brancos e negros ao longo da colonização. A título de exemplificação, no Brasil, D. Pedro II se tornou príncipe regente aos cinco anos de idade, com todas as honrarias inerentes à posição política. No âmbito caribenho, Xavière, um pouco mais velha do que D. Pedro II, viu Rosalie se juntar a um séquito de outros quatro escravizados cuja função na 
fazenda era pajear a sinhazinha. Como se sabe, as crianças brancas desfrutavam do poder familiar, tinham uma comitiva para lhe agradar e lhe suprir todos os caprichos, dispunham de segurança, usavam as melhores roupas, calçavam sapatos, recebiam a melhor alimentação, dormiam em quartos luxuosos na casa grande, podiam estudar com preceptoras qualificadas, usufruíam de conforto e de lazer e contavam com atendimento médico, quando necessário. Na contramão desta infância-branca-idílica, "a vida esmerilou com força" (SILVA, 2013, p. 48) os pequenos negros escravizados, que iam "andando com fome, sede e descalços, suados" (SILVA, 2013, p. 65) numa jornada que Ihes impunha "além da queda, coice" (SILVA, 2013, p. 72).

A passagem em tela de La mulâtresse Solitude retrata o fato de que a abrupta separação entre mãe e filha ocasionou na pequena uma gagueira jamais corrigida, o que sublinha os reiterados e diversos aviltamentos impingidos aos escravizados; aviltamentos marcados no corpo tal como cicatrizes cúmplices da infortunada jornada. É mister se levar em conta que a menina Rosalie não tinha a figura paterna e se vê arrancada dos braços da mãe para ser ofertada como boneca à filha do patrão. Desta forma, o início da vida laboral se dá sob o prisma da orfandade, da 
solidão e da vulnerabilidade lancinantes. Para buscar corrigir a deficiência da escravizada, afinal seria desejável ofertar à filha um brinquedo em perfeitas condições, o dono decide, num rompante e sem qualquer conhecimento médico, Ihe cortar a sangue frio parte da língua, buscando curá-la da gagueira agoniante aos ouvidos dos mestres. Este episódio de mutilação física se soma à outras dores acumuladas ainda na tenra infância. Mais uma vez, seu corpo se vê ultrajado sem a menor parcimônia, para que se adeque à ordem colonial das coisas e ao gosto dos proprietários.

Neste contexto, ocorre-me a contundente sentença "a infelicidade do homem, já dizia Nietzsche, é ter sido criança" (FANON, 2008, p. 28, grifo do autor), da qual o intelectual e psiquiatra martinicano Frantz Fanon se apropria, na tentativa de estudar as neuroses advindas da subalternização negra manifestada por antilhanos na França. Fanon mobilizou um arcabouço psicanalítico para explicar o "complexo de inferioridade" (FANON, 2008, p. 134) que assolava os negros em contato com os brancos e nomeou de a "psicopatologia do negro" (FANON, 2008 , p. 127) os distúrbios psíquicos oriundos destes enfrentamentos identitários e sociais. A frase de Nietzsche está presente duas vezes em Pele negra, máscaras brancas 
(1952, na publicação original em francês. No Brasil, houve três traduções: 1963, 2008 e 2020).

A primeira ocorrência, que já foi mencionada, é seguida pelo trecho "entretanto não podemos esquecer, como lembra Charles Odier, que o destino do neurótico está nas suas próprias mãos. Por mais dolorosa que possa ser esta constatação, somos obrigados a fazê-la: para o negro, há apenas um destino. E ele é branco" (FANON, 2008, p. 28). A segunda citação aparece na parte final do livro. Nela Fanon declara: "Um homem, no início de sua existência, é sempre congestionado, envolvido pela contingência. A infelicidade do homem é ter sido criança" (FANON, 2008, p. 191). Ao incluir a tese de Nietzsche em sua obra sobre a condição dos negros, Fanon atribui novos contornos à defesa feita pelo filósofo alemão da infância como momento de vivência de traumas que carregaremos, por espelhamento, para na vida adulta e que forjarão nossas bases egóicas. Reacomodada no território fanoniano, a infância e a infelicidade se dirigem aos negros, cujas vidas foram irremediavelmente transpassadas pela experiência colonial. Fanon busca nos dizer que se a infelicidade do homem em geral são os traumas que ele carrega da infância, a infelicidade dos negros é ter sido uma criança desapropriada, rasurada, impedida, silenciada 
e coisificada, para retomarmos o termo cunhado por Aimé Césaire. As mazelas desta infância se arrastarão como correntes ao longo da vida adulta (quando o escravizado chegar a este estágio, visto a baixíssima expectativa de vida), se imprimirão nas gerações futuras e seguirão repercutindo nos dias de hoje, como veremos mais adiante.

Outros trechos do romance de André Schwarz-Bart oferecem imagens detalhadas da infância de Rosalie. Após o brutal episódio da língua cortada, segue-se a preparação do "brinquedo" antes de iniciada sua vida de pajem, na qual Sr. Mortier ordena, "lava-me esse diabo" (SCHWARZBART, 2005, p. 66) e a menina toma banho, após o qual foi aferido que "o cheiro a negro tinha desaparecido" (SCHWARZ-BART, 2005, p. 67). Ao ofertar a menina à filha, o pai estava "radiante" (SCHWARZ-BART, 2005, p. 67). Logo após, Xavière formula uma pergunta para Rosalie, que Ihe responde "s-sim" (SCHWARZ-BART, 2005, p. 68), ao que se seguiu uma cena que o pai observou "não sem emoção" (SCHWARZ-BART, 2005, p. 67), na qual "Xavière franziu as sobrancelhas e disse com ar zangado: 'Tens de dizer sim, minha senhora'" (SCHWARZ-BART, 2005, p. 67). Diante da audácia de Rosalie, a sinhazinha foi encorajada por seus quatro pequenos escravos a dar-lhe um "correctivo" 
(SCHWARZ-BART, 2005, p. 67) e "com quatro estacas" (SCHWARZ-BART, 2005, p. 67), para cortar imediatamente a petulância da recém-chegada. Prontamente,

a curiosa mulatinha deitou-se sobre a barriga, sem dizer uma palavra, depois de ter devidamente levantado a sua saia acima dos rins, enquanto cada um dos outros escravos a segurava pelos tornozelos e pelos punhos. E, por fim, a pequena senhorita pegou um encantador chicote com cabo de osso, e ergueu-o com um esgar semelhante ao do capataz...

Neste momento, o Sr Mortier abafou um lamento e, numa espécie de iluminação súbita, entreviu a maldição para a qual o escravo arrasta o seu senhor. (2005, p. 67)

Inicialmente, Sr. Mortier cuida da higiene de Rosalie para que ela seja entregue em sua melhor versão para a filha. Não causa incômodo ao proprietário as negligências que impõe aos escravizados e as privações no autocuidado no dia a dia. Contudo, para adentrar sua casa e desfrutar do convívio da pequena patroa, seria necessário tirar do corpo o mau odor que, segundo ele, caracterizaria os negros. A empreitada colonial desvela o escárnio dos colonos contra os escravizados, por intermédio, dentre outros, de depreciações diversas contra o corpo destes. Séculos depois, encontramos, com regularidade, ecos deste alarido repugnante. Não são raras as notícias de xingamentos e/ou 
'opiniões' nesse caminho, como, por exemplo, a de Avelino Grota, promotor de Justiça do Ministério Público do Estado de São Paulo, em 2017, segundo o qual "negro, como todos sabem, tem o péssimo costume de não dar muita atenção à higiene" e "negro, em geral, é catinguento, porque sua muito e, não tomando a quantidade diária certa de banhos, acaba fedendo mais do que o recomendável" (GROTA apud AFFONSO; MACEDO, 2017). Trata-se, como declara a ativista negra Joice Berth, de episódios de "massificação dos estereótipos desumanizadores que pessoas negras sofrem, como consequência das dinâmicas que atuam no sistema racista" (JUSTIFICANDO, 2017).

Em seguida, o narrador do romance focaliza as hierarquias linguísticas oriundas de esquemas de poder e subordinação. De um lado, Rosalie, com língua mutilada, a boca em chagas, gaguejando, sendo ensinada a respeitar as formas de tratamento coerentes com as regras sociais. A este respeito, Fanon nos faz um convite: "Observem que, nos periódicos ilustrados para crianças, todos os negros têm na boca o 'sim sinhô' ritual" (FANON, 2008, p. 47). Do outro lado, Xavière, que mistura o ensinamento com a punição, para coibir qualquer tipo de desrespeito que Ihe mostrasse vulnerável aos olhos dos familiares e dos 
demais pajens. Uma menina sinhá sob o vocativo de "minha senhora", envelhecida pelos protocolos linguísticos que não permitiam que as crianças fossem crianças na colonização. Coaduna-se à maldade da sinhazinha, a falta de empatia dos demais escravizados, que rapidamente oferecem um cardápio de castigos físicos a serem infligidos na recémchegada. Tudo leva a crer que se estes admitissem que Rosalie usufruísse de alguma regalia, estariam ainda mais subjugados em suas submissas funções. Por fim, a maneira calma como a escravizada se estende ao chão e oferece o corpo aos castigos da patroa expõe o esfacelamento de sua infância. Desde pequena, como preconiza a condição dos colonizados, ela se mostra esvaziada de vontades e refém de todo o tipo de penitência. Até as reações e recusas lhe foram subtraídas. Nada ou quase nada parece the restar.

Eis como se conclui a cena do castigo físico:

Em vez de baixar o chicote, a divertida criança acariciou docemente a nuca de sua noviça e desarou a rir, imediatamente imitada pelos seus companheiros. Depois levantou a pequena com as suas próprias mãos e disseIhe a sorrir: 'Eu não sou como minha irmã Adelaïde, nunca brinco com o chicote. Mas tem de me tratar por 'minha senhora', senão o meu pai não ficará contente e a minha irmã vai gozar comigo. Combinado? (SCHWARZBART, 2005, p. 67-68) 
O desfecho surpreendente poderia sugerir uma bondade da sinhazinha, uma criança, ela também, de alguma maneira, peça de uma engrenagem colonial que ditava seus passos. $\mathrm{O}$ afeto ou a piedade deveriam ser camuflados, reprimidos. Contudo, não se pode ignorar a intimidação flagrante na 'brincadeira' de brandir o chicote e forçar Rosalie a se estender no chão. Havia um jogo interpessoal que deixava clara as posições de cada um. A cena, nestes termos, retrata como se davam as 'brincadeiras'. O riso de Xavière, por sua vez, ganha aura irônica, regozijo em ver seu protagonismo aflorado perante o apequenamento silencioso dos demais. Ela ri por duas vezes da performance que humilha os demais; seu contentamento se mostra proporcionalmente inverso aos sentimentos de inquietação que desencadeia. O pedido final lançado para a novata nada mais era do que uma retórica insidiosa que dava ordens descartando qualquer anuência.

O narrador se apressa a ilustrar outras atitudes de Xavière, para que não pairem dúvidas acerca da verdadeira índole de suas 'brincadeiras'.

Nunca falava de esfolar, de limpar os ossos da carne podre que os envolve, de obrigar a dormir três meses sobre os cotovelos, de rabo para o ar, Mas, segundo Duas-Almas tinha algumas brincadeiras eminentemente 
lamentáveis. Assim, quando uma de suas cocottes the desagradava, dizia-Ihe: 'Vou vender-te ao Sr. Chaperon. Chaperon era um habitante da vizinhança, que tinha feito entrar um dos seus negros num forno quente. (SCHWARZ-BART, 2005, p. 70, grifo do autor)

Além disso, a respeito de Rosalie, "muitas vezes a menina Xavière mantinha-a ao pé de si durante a noite. Uma simples esteira no chão era suficiente para ela" (SCHWARZ-BART, 2005, p. 71). Não restam dúvidas de que a dinâmica na casa dos Mortier se move pelo paradigma do amedrontamento e da ameaça notória. Assim, parece contraditório o desejo do pai ao presentear a filha. Se, por um lado, ele maltrata de todas as formas o 'brinquedo' da menina, por outro, parece se entristecer quando esta faz (ou parece fazer) uso da violência. Segundo o narrador, ele queria ver sua filha fora desta maldição, que ele não hesita em alimentar, ao achincalhar Rosalie, separá-la da mãe, mutilá-la, condená-la por sua cor, seu cheiro, sua gagueira. Como ensinar a filha um comportamento em dissonância com o exemplo paterno? É curioso observar que o progenitor enseja uma infância-outra para sua rebenta, busca poupá-la desta difícil relação com os cativos, a quem acusa dos males da colonização. Cria-se a narrativa falaciosa de que é a rebeldia dos negros que força os brancos a serem brutos, à revelia de suas vontades e ímpetos. 
No início da vida na casa grande, "dir-se-ia [de Rosalie] um brinquedo mecânico, uma daquelas bailarinas que rodam e viram sobre algumas notas delicadas e depois se imobilizam subitamente" (SCHWARZ-BART, 2005, p. 82), “descobriria subitamente um prazer extraordinário, do qual nunca tinha suspeitado, em aparentar servilismo" (SCHWARZ-BART, 2005, p. 74). A imagem se mostra precisa para cartografar a menina escravizada como alguém inerte cujas cordas são movidas pelas mãos brancas. Estas mãos estabelecem as horas, a rotina e transformam o outro numa extensão de seus quereres e ações. Aterrorizadas e sozinhas, as crianças cedem, pois não conhecem a geografia da fazenda, não têm para onde fugir, não possuem aliados e imaginam, em seu âmago, um retorno da mãe para buscá-las. Tudo leva a crer que, na primeira infância, a sobrevivência repousa na mais eficaz adequação à dinâmica escravagista em vigor.

Entretanto, a rápida acomodação de Rosalie à condição dos negros não lhe acompanhou ao longo de toda a narrativa. Em pouco tempo, ela passou a apreciar "praticar o mal" (SCHWARZ-BART, 2005, p. 74, grifo do autor), envenenando as galinhas "para sua própria satisfação e em função do seu próprio prazer" (SCHWARZ-BART, 2005, p. 74, grifo do autor). Ela passa a cometer pequenos delitos e se 
alegra em gerar preocupações, alterar 'a ordem natural' das coisas, causar prejuízos. Em outras palavras, seus desvios de conduta parecem soprar vida para dentro de um corpo anteriormente lobotomizado, fragilizando os ciclos de opressões e subalternizações que se impuseram com facilidade por mãos adultas. Em dado momento da intriga, Xavière discorre sobre a insensibilidade dos negros à dor: "Duas-Almas sabia certamente que os negros não sentem a dor como os brancos? - Toda gente sabe disso, minha senhora - dizia Duas-Almas aterrorizada" (SCHWARZ-BART, 2005, p. 71). A menina indiferente e resiliente cede lugar a alguém que se assombra com os impulsos da sinhazinha, discorda de suas opiniões. Esta mudança de comportamento lançará as bases para o afastamento entre Rosalie e seu papel de boneca, impelindo a escravizada a se tornar, com o tempo, uma moradora de quilombo, líder da resistência antiescravagista e anticolonial.

As peripécias da infância da jovem escravizada Rosalie no arquipélago caribenho encontram ecos nas imagens da infância da obra Água de barrela, da escritora brasileira Eliana Alves Cruz. Publicado em 2016, o livro marca a estreia ficcional da jornalista carioca, cuja tessitura literária tira partido dos diálogos promissores entre os campos da história e da 
ficção. Na composição de seus romances históricos, Eliana se debruça em dados e vultos históricos, buscando inscrever, nas entrelinhas e nos silenciamento da história oficial, narrativas de anônimos e suas resistências quotidianas. Em outras palavras, "o romance faz renascer diante dos olhos dos leitores personagens que são constantemente apagadas e desautorizadas do discurso da história brasileira enviesado por falsas noções de uma democracia racial" (MARINGOLO, 2020, p. 2). Graças à Água de barrela, a autora foi laureada com uma moção de aplausos, outorgada pela Câmara dos vereadores do Rio de Janeiro, em 8 de setembro de 2016. O romance recebeu menção honrosa do Prêmio Thomas Skidmore, em 2018, do Arquivo Nacional e da universidade americana Brown University.

Água de barrela sagrou-se vencedor do I Prêmio Literário Oliveira Silveira. Promovido, em 2015, pela Fundação Cultural Palmares/Ministério da Cultura, o concurso fomenta a publicação de romances centrados na realidade afro-brasileira. Em sua segunda edição, em 2018, o livro integrou o portfólio da editora carioca Malê, editora voltada para publicações de autores e autoras afrodescendentes. A obra se debruça na trajetória da própria família da autora, desde meados do século XIX, na África, até nossos dias. Logo 
nas primeiras páginas, vê-se fotografias da família, seguidas de uma árvore genealógica que se inicia em 1849, no reino de Oió, oeste africano, e se estende até o século XXI, com menção os descendentes da autora e de seus irmãos. Ao todo, a árvore ilustra pelo menos oito gerações, sendo duas delas mais detalhadamente acolhidas nas narrativas de Alves Cruz, seus bisavós Damiana e João Paulo e seus tataravós Martha e Adônis.

No epílogo "Sobre como este livro aconteceu", Eliana discorre sobre o processo de pesquisa e de redação de Água de Barrela, que perfaz um caminho vislumbrado por ela desde a adolescência: "desde a adolescência, muita coisa me intrigava, e a vontade de pesquisar mais fundo para depois escrever ia sendo postergada pelo sufoco da rotina e da vida" (CRUZ, 2018a, p. 308). Para além de fotografias familiares e objetos com suas histórias a recompor, a narrativa se impulsiona valorizando a escuta da tia Anolina, cujos "poucos relatos disseram quase tudo" (CRUZ, 2018a, p. 308): "eu anotava quase tudo o que podia e partia para pesquisar. Todas as informações conferiam com registros históricos, com a descrição dos locais, com informações de residentes e amigos que são competentes pesquisadores" (CRUZ, 2018a, p. 309). Assim, tecendo uma colcha de retalhos com pontos 
de pesquisa, testemunhos e análise de objetos, a obra consiste em uma ode à ancestralidade africana, contribuindo para que os país reencontre suas origens e sua identidade. 0 romance reconecta o Brasil à história da diáspora africana, a partir dos quais compusemos nossa "amefricanidade", explicada pela filósofa e antropóloga brasileira Lélia González nestes termos:

Para além do seu caráter puramente geográfico, a categoria Amefricanidade incorpora todo um processo histórico de intensa dinâmica cultural (adaptação, resistência, reinterpretação e criação de novas formas) que é afrocentrada. [...] a Améfrica, enquanto sistema etnogeográfico de referência, é uma criação nossa e de nossos antepassados no continente em que vivemos, inspirados em modelos africanos. [...] Assumindo nossa Amefricanidade, podemos ultrapassar uma visão idealizada, imaginária ou mitificada da África e, ao mesmo tempo, voltar o nosso olhar para a realidade em que vivem todos os amefricanos do continente. (GONZALEZ, 1988, p. 76-78)

Ao reiterar as atrocidades da infância ao longo da colonização, a intriga de Água de barrela, de Eliana Alves Cruz, propõe um olhar para a infância de crianças negras escravizadas, constantemente violadas, mutiladas e castigadas. O capítulo intitulado "brinquedo humano" acaba por fazer o leitor reviver a relação entre Rosalie e Xavière, 
de La mulâtresse Solitude. Distanciados por mais de quatro décadas, ambos os romances apresentam olhares muito convergentes sobre a desumanização de meninas negras, meninas rebaixadas a bonecas sobre as quais são desferidos numerosos açoites. Eis as palavras do narrador:
A cada encontro, Firmino reparava que Anolina estava mais alta e que seu corpo começava a mudar. Preocupou-se com a sobrinha. Sabia o que acontecia às negrinhas assim que começavam a "botar corpo". O filho do barão estava crescendo, ele era pouco mais novo e ela bem poderia ser seu "brinquedo humano". De certa forma, ela já era parte de seu divertimento, pois entre suas muitas tarefas na casa, uma era a de brincar com o pequeno Francisco, que não se constrangia em mordê-la, esbofeteá-la e reproduzir com ela o que via no tratamento dos pais, avós e tios aos negros. (CRUZ, 2018a, p. 87)

Mais uma vez, as tramas literárias levam ao cabo a representação da "coisificação" de crianças, que se tornam marionetes submetidas à fúria de outras crianças. Dentre as brincadeiras do sinhozinho, todo o tipo de ofensiva contra o corpo da pequena Anolina. As frequentes investidas sobre a menina se inscreviam nas lições de sua formação como herdeiro da casa grande; daí advinha seu poder, sua masculinidade, sua virilidade. Aprendia desde cedo a 
ultrajar o corpo feminino, o que faria na vida adulta, em menor escala, com a esposa branca, com quem se unirá em um enlace arranjado e, em voltagem altíssima, com as mancebas negras obrigadas a com ele se deitar. Em sua infância, descobria o prazer de subjugar a menina, testando suas maldades e compondo um repertório infame. É preciso salientar que os meninos, quando não trabalhavam junto aos adultos escravizados, se ocupavam como moleque de recados e carregadores de compras, além de fazer reparos e serviços diversos de manutenção na fazenda. Cabia às meninas o auxílio à lavadeiras, faxineiras e cozinheiras, além da função de pajens de companhia de sinhazinhas e sinhozinhos no âmbito familiar. O certo é que "na condição de aprendiz deviam estar muitas dessas crianças" (TEIXEIRA, 2010, p. 87). “As atividades de candeeiro, pastor, campeiro, assim como os ofícios de carpinteiro, sapateiro, alfaiate, tropeiro, mineiro e serrador também apareceram como masculinas. As meninas predominavam nos serviços domésticos" (TEIXEIRA, 2010, p. 86).

Outro trecho do romance brasileiro detalha as imagens da infância de negras escravizadas:

Certa vez, o menino cortou com uma faca as tranças de Anolina, que já estavam bem grandes e grossas, pois queria que ela parecesse um garoto. Isabel, quando viu o 
moleque com a faca enorme e afiada em uma das mãos e o cabelo da menina em outra, não conseguiu reprimir o grito. $O$ barulho chamou a atenção de dona Carolina, que descansava, por estar com uma forte dor de cabeça. Irritada, a sinhá bateu violentamente em Isabel.

- Como se atreve a perturbar e interromper meu descanso por conta de tolices de crianças, sua idiota? (CRUZ, 2018a, p. 87)

A cena reforça a violência colonial, com o manejo de objetos pontiagudos voltados para o corpo de Anolina. Tanto quanto Sr. Mortier, que decide ao léu cortar a língua de Rosalie, o menino não hesita em cortar as tranças de sua boneca, ressaltando que absolutamente nada em seu corpo pertence a ela. É preciso levar em conta que a menina apresentava cabelos bem cuidados que inspiravam cuidados e despertavam orgulho. Era uma das poucas coisas que podia chamar de sua. Na cena da mutilação, junto aos cabelos que caem, se esvaem a vaidade, o amor próprio e a possibilidade de se cuidar da autoestima, a despeito do entorno escravista. Enquanto Xavière ameaça seu séquito com narrativas sobre escravizados lançados ao forno, Francisco, apesar da idade, impunha armas brancas. A mutilação dos cabelos ocorre dentro da rotina da casa, sendo considerada uma tolice de criança pela mãe do menino. Certamente, sua reação seria outra, caso as mechas cortadas fossem de uma de suas filhas 
ou netas. A cena traz à tona o fato de que os atos apresentam ou não gravidade em função menos de sua natureza que de seus atores, o que valida a clivagem entre as infâncias de brancos e negros no período colonial. O tapa final desferido contra a serviçal que se assusta reitera a ordem colonial, no qual o silêncio se impõe para os escravizados. Assim, o trecho demonstra ser a dor e a violência os lugares simbólicos de solidariedade e de comunidade dos cativos.

Em seguida, o narrador prossegue a intriga:

O garoto também estalou um tapa no rosto de Anolina. A menina chorou compulsivamente na cozinha e foi consolada por Umbelina, que Ihe arrumou um pano colorido e amarrou num belo turbante à moda de sua terra natal, Ibadan. Francisco era um rei e o sobrado do engenho o seu castelo. Ele nunca estava errado, sempre tinha razão. Poderia fazer o que fosse. (CRUZ, 2018a, p. 88)

Ele acaba por dizer com todas as letras as diferentes condições entre brancos e negros manifestada de maneira irrefutável nos atos de crueldade e de sujeição. Francisco, ao desferir o tapa em Anolina, prolonga o efeito dominó das agressões ensinadas pelos modelos maternos e paternos, como já ocorrera entre Sr. Mortier e sua filha. A violência faz escola, os gestos são reproduzidos de maneira mecânica, 
não sem o gosto entorpecedor da demonstração de poder. Um tempo depois, o brinquedo humano se torna companhia de alcova, destino intransponível das negras-cativas. Para tal, Umbelina

deveria preparar Anolina para dormir com Francisco na noite do aniversário. $\mathrm{Na}$ verdade, o senhor ia revelando, ela tinha sido mantida até aquele momento por perto e intacta para que fosse a 'estreia' de Francisco aos 13 anos. O barão queria que a moça estivesse bonita para o filho e pediu para Umbelina "caprichar" [...] Os homens saíram para o quarto anexo e deixaram Francisco a sós para desfrutar o "regalo". (CRUZ, 2018a, p. 89-90)

Dentre as disparidades entre as infâncias, estamos diante do fato de que, para Francisco e seu clã, a perda da virgindade da menina era um presente enquanto para Anolina, o estupro se revela um divisor de águas em sua queda, como descreve o narrador: "Anolina estava perdida, se afogando na mágoa por ter descoberto o objeto que sempre fora" (CRUZ, 2018a, p. 92). Mais uma vez, tanto quando Rosalie que foi banhada e preparada para ser entregue à Xavière, Anolina mereceu cuidados para agradar à volúpia do menino, em seu ritual de passagem para o mundo dos homens. Ao fim, experiências como as das meninas vilipendiadas nos romances em tela causarão 
transtornos emocionais e sociais de múltiplas ordens que não serão esquecidos. "Todos sabem que a personalidade se firma pouco a pouco na criança, que ela se define majoritariamente em relação ao olhar do outro" (CONDÉ, 2015a, p. 13). Nestes termos, se o que o outro oferece é sempre depreciativo, humilhante e degradante, a criança terá dificuldades em ver o mundo e se desenvolver fora desta redoma negativa e limitadora.

Os diversos usos de crianças escravizadas como brinquedo nas mãos dos mais poderosos não se limitou ao período colonial, embora ele tenha sido significativo na promoção da hierarquização dos seres e na desumanização dos negros. É oportuno salientar que "as antigas práticas coloniais deixaram resquícios" (ALMEIDA, 2019, p. 125) que operam vigorosamente na contemporaneidade e que "submetidos às pressões de uma estrutura social racista, o mais comum é que o negro e a negra internalizem a ideia de uma sociedade dividida entre negros e brancos, em que brancos mandam e negros obedecem" (ALMEIDA, 2019, p. 68). E neste momento, a análise empreendida sobre as imagens da infância chega em sua parte final, na qual se observa a incidência de violências pós-coloniais e de "brincadeiras" contra o corpo e a integridade sentimental 
de crianças negras. Em alguma medida, lamentavelmente, o destino experienciado pelas meninas Rosalie e Anolina se imprime em corpos negros vulneráveis nos dias de hoje. O modos operandi colonial se mantém vivo, massacrando aqueles seres transpassados pelo racismo estrutural e pelas profundas desigualdades sociais e econômicas. Dados do Fundo das Nações Unidas para a Infância (Unicef), replicados pela Agência Brasil, revelam que "64,1\% das crianças e adolescentes em trabalho infantil em 2016 eram negros, assim como 82,9\% das vítimas de homicídios entre 10 e 19 anos e $75 \%$ das meninas que engravidam entre 10 e 14 anos" (LISBOA, 2020). Mario Volpi, coordenador do Unicef, afirma que "uma criança negra tem três vezes mais possibilidades de abandonar a escola que crianças não negras" (LISBOA, 2020).

A escritora guadalupense Maryse Condé e a brasileira Conceição Evaristo cartografam as heranças da colonização nestes tempos em que se erguem operadores decoloniais e o desejo de passar a limpo a história do escravagismo. Neste sentido,

a descolonização jamais passa despercebida porque atinge o ser, modifica fundamentalmente o ser, transforma espectadores sobrecarregados de inessencialidade em atores privilegiados, 
colhidos de modo quase grandioso pela rodaviva da história. Introduz no ser um ritmo próprio, transmitido por homens novos, uma nova linguagem, uma nova humanidade. A descolonização é, na verdade, criação de homens novos. Mas esta criação não recebe sua legitimidade de nenhum poder sobrenatural; a 'coisa' colonizada se faz no processo mesmo pelo qual se liberta. Há portanto na descolonização a exigência de um reexame integral da situação colonial. (FANON, 1968, p. 26-27)

A narrativa Un coeur à rire et à pleurer - contes vrais de mon enfance [Um coração a rir e a chorar - contos verdadeiros da minha infância], da escritora Maryse Condé, promove um emocionante reexame da situação colonial. Publicado em 1999, o romance foi laureado com o Prêmio Marguerite Yourcenar, outorgado para um escritor de língua francesa morando nos Estados Unidos. A autora Maryse Condé recebeu uma infinidade de prêmios ao longo da profícua carreira, dentre os quais se destaca o prêmio da Nouvelle Académie, conhecido como o Nobel alternativo de literatura, em 2018, pelo conjunto da obra. No ano seguinte, foi homenageada com a Grande Cruz da Ordem nacional do mérito, na França, e teve seu nome em alta nas bolsas de aposta para o Prêmio nobel de literatura de 2020, o que acabou sendo outorgado para a poeta norte-americana Louise Glück. 
Un cœur à rire et à pleurer apresenta dezessete contos através dos quais a autora descortina, assumindo o tom autobiográfico da narração em 1a pessoa, episódios marcantes da sua infância. Intitulado de "Lição de história", o quinto conto da coletânea passa em revista episódios de agressões durante brincadeiras de uma menina branca, chamada Anne-Marie de Surville, contra a menina Maryse Condé. De início, Anne-Marie faz ressalvas à menina que acabara de conhecer numa praça: "Nós vamos brincar! Mas tome cuidado, minha mamãe não deve me ver com você, senão ela me bateria. [...] Eu estava feliz demais por encontrar uma parceira da minha idade, mesmo que ela me mandasse como se eu fosse sua empregada" (CONDÉ, 2015, p. 48). Maryse Condé era filha temporã de uma família que já contava com sete filhos. Ela passou a infância entre sua cidade natal, Pointe-à-Pitre, capital de Guadalupe, e Paris, "sede do poder colonial" (CONDÉ, 2015b, p. 11). Em Pointe-à-Pitre, a menina vivia numa redoma e quase não tinha coleguinhas. Seus pais desencorajavam que ela se expressasse em língua crioula e eram "um par de alienados" (CONDÉ, 2015b, p. 15) na relação de adoração à França e na crença de que "somente vale a pena existir a cultura ocidental" (CONDÉ, 2015b, p. 18). 
Anne-Marie de Surville era "loira, desalinhada, um rabo de cavalo sem graça nas costas" (CONDÉ, 2015b, p. 47) e Maryse, por sua vez era "feia" (CONDÉ, 2015b, p. 26). Enquanto esta se contentava em ser maltratada para amizades, aquela não fazia questão de esconder que não deveria brincar com negrinhas. Talvez, a crença de que a outra se arriscava para estar em sua companhia fizesse com que Maryse relevasse comportamentos estranhos, frases ríspidas, alguns esbarrões, em um círculo de violência que só fez crescer. É importante reconhecer que "naqueles tempos em Guadalupe, as pessoas não se misturavam. Negros andavam com negros. Mulatos com mulatos. Os brancos-país permaneciam em sua esfera e o Bom Deus ficava contente no céu" (CONDÉ, 2015b, p. 62). Assim se realizavam as brincadeiras:

Anne-Marie assumiu a gestão dos nossos jogos e durante toda a noite, me submeti aos seus caprichos. Eu era a má aluna e ela puxou meu cabelo. Além disso, ela puxou meu vestido para me bater. Eu era o cavalo. Ela subiu nas minhas costas e chutou minhas costelas. Eu era a empregada e ela me golpeou. Ela me dirigia muitos palavrões. [...] Finalmente, a palmada final me machucou tanto que corri me refugiar nos braços de minha mãe. Com vergonha, não expliquei nada". (CONDÉ, 2015b, p. 48) 
O episódio traz à tona incredulidade da menina que, a despeito de fazer todas as concessões, acaba reiteradamente humilhada e inferiorizada pela coleguinha. Sob esta perspectiva, é pertinente observarmos o jogo de palavras presente no termo "Surville", sobrenome da menina agressora. Trata-se da preposição "sobre" e do substantivo "cidade". Tal disposição sugere uma supremacia para a menina, que está situada acima da cidade, nas alturas, e, por consequente, em um lugar de privilégios mais elevado do que os demais. Anne-Marie não se encontra no mesmo nível dos outros, estes não são páreos para ela. A respeito do conflito das duas crianças, Maryse entendia que havia alguma coisa errada, mas não sabia o que motivava tal comportamento da loirinha de tranças. O que haveria ela feito para desencadear tanta fúria? Por que as brincadeiras giravam em torno de Maryse sendo montada, xingada, achincalhada? Por que Ihe eram destinados repetidamente os papéis de aluna com dificuldade, de cavalo e de empregada? Ela só queria brincar e "o jogo, tão importante no universo infantil" (CONDÉ, 2015a, p. 17), "pode ser concebido como uma iniciação à vida" (FANON, 2008, p. 41). E, como confessa em suas narrativas, a vida-infância de Maryse Condé se estrutura em cima de desmandos, de hierarquias, de 
rejeições e de hostilidades. Os embates continuaram, como conta a adulta Maryse Condé:

No dia seguinte, Anne-Marie estava me esperando no mesmo lugar. Durante mais de uma semana, ela foi fiel ao posto e eu me rendi sem protestar a seus abusos. Depois que ela quase me nocauteou, eu finalmente protestei, cansada de sua brutalidade:

- Eu não quero que você me bata mais. (CONDÉ, 2015b, p. 49)

Diante do limite imposto pela pequena, Anne-Marie "zombou e me deu uma cutucada cruel na boca do estômago: - Tenho que te bater porque você é negra. Eu tive força para me afastar dela" (CONDÉ, 2015b, p. 49). E eis que impedida de seguir esbofeteando sua "boneca", a menina revela o "salvo-conduto" social que alimenta seus atos. A narradora continua a narrar o périplo:

No caminho de volta, não importa o quanto eu pensasse em sua resposta, não encontrei nenhuma razão. Na hora de dormir, após as orações para os vários bons anjos da guarda e a todos os santos do céu, perguntei à minha mãe:

- Por que temos que bater nos negros?

Minha mãe parecia atordoada, ela exclamou:

- Como pode uma menina tão esperta como você fazer tais perguntas?

Ela rapidamente desenhou um sinal da cruz na minha testa, levantou-se e recuou desligando a luz do meu quarto. (CONDÉ, 2015b, p. 49) 
O trauma da pequena Maryse advém de uma dupla incompreensão. Por um lado, a frase em riste lançada por Anne-Marie sobre agressividade dirigida aos negros e, por outro lado, o silêncio materno, a recusa da família em explicar o racismo estrutural e os resquícios da escravização. Para compreender a dificuldade materna, é preciso levar em conta que ela que "a mãe não se preocupava com problemas sociais" (CONDÉ, 2015b, p. 23) e que os Condé eram "uma família de negros que se tomava pelo que eles não eram" (CONDÉ, 2015b, p. 42), que os pais "não sentiam o mínimo sentimento de inferioridade por causa da cor deles" (CONDÉ, 2015b, p. 18). Sobre a mãe, Condé relata: "sofri principalmente com as meias de dois tons muito claros para sua bela tez que mamãe usava no calor" (CONDÉ, $2015 b$, p. 16). Os pais se consideravam mais franceses que os franceses, viviam sob a égide de um branqueamento mental e faziam vistas grossas a situações de intimidação.

A narradora revela nas linhas finais do conto:

Hoje, eu me pergunto se esse encontro não foi sobrenatural. Já que há tantos ódios antigos, velhos medos nunca liquidados permanecem enterrados no solo de nossos países, eu me pergunto se Anne-Marie e eu, não fomos, no espaço dos nossos chamados jogos, as reencarnações em miniaturas de uma proprietária e seu escravo. (CONDÉ, 2015b, p. 51) 
Neste contexto, o título de "Lição de história", atribuído ao conto se elucida. A mão agressiva e impiedosa de Anne-Marie retoma as mãos de Francisco, de Xavière e de tantos outros sinhôs e sinhás - de ontem e de hoje que não se apartam de seus "chicotes" em riste diante de negros e negras. Trata-se, provavelmente, de uns dos primeiros episódios da menina diante dos legados nefastos da escravização do período colonial, que cindiu de maneira profunda a relação entre brancos e negros. Estas feridas estão cada vez mais sendo nomeadas e denunciadas quer seja por intermédio de expressão artísticas quer seja por outros instrumentos, como coletivos negros, leis e projetos de lei e denúncias de atos inaceitáveis pela imprensa.

O título do livro Un cœur à rire et à pleurer, Coração a rir e a chorar, em tradução livre, coloca, por sua vez, em evidência as intempéries e os sofrimentos da infância. Considero curiosa a ordem da disposição dos termos "rir" e "chorar" na obra. Não se trata de uma ordenação que se inicia pelo choro para, em seguida, mencionar o riso, sugerindo uma catarse e uma superação, na sinergia dos provérbios otimistas "não há mal que dure para sempre" ou "depois da tempestade, a bonança". Dispostos como estão, primeiro o riso e depois o choro, tudo leva a crer que o choro se mostrava à espreita com alguma regularidade. 
Reconheço nesta coletânea de Condé elementos característicos do que Dominique Viart considerou ser os romans de filiation (narrativas de filiação), categoria assim descrita pelo pesquisador francês.

Esses livros focaram seu interesse em questões familiares, mais precisamente genealógicas, explorando as figuras paternas ou maternas, às vezes uma ancestralidade mais distante, mas sempre de acordo com uma abordagem singular, mais arqueológica do que cronológica. Longe de contar biografias lineares, os narradores e narradoras se propõem a restitui-las usando uma busca memorial a partir da qual eles contaram a história e os elementos dispersos. (VIART, 2019, p. 10-11)

Aprofundando as análises acerca deste tipo de narrativa, Dominique Demanze explicita que

a narrativa de filiação ancora-se, de fato, no próprio local de uma ferida, entre o testemunho impedido e a oferenda às figuras passadas da ascendência. $O$ escritor contemporâneo examina as antigas horas em busca de vestígios apagados de um passado desaparecido, como se algo incompleto em suspenso - assombrasse o presente. (DEMANZE, 2008, p. 10)

Como vimos, a perspectiva de feridas que assombram o presente se apresenta de maneira vigorosa neste livro de Condé. Nascida em 1934, a autora publica, em 1999, 
uma obra voltada para as peripécias de sua infância. Ora, isto ocorre com uma distância temporal de mais de cinco décadas. É notável, igualmente, o fato de esta obra inaugurar a incursão da escritora Maryse Condé no gênero do "récit" (narrativa). Até então ela havia redigido mais de uma dezena de romances, seis peças de teatro, numerosos contos, além de atividades no campo da organização de antologias, na redação de ensaios e na tradução. Assim, ao decidir trilhar caminhos mais pessoais e intimistas, por assim dizer, ela elege sua infância e empreende um retorno a esta fase. Ao longo da obra, é inegável que as dores e as incompreensões perante alguns acontecimentos da infância preservaram seu frescor e se revelaram lancinantes. Sentenças como "hoje, eu me pergunto" (CONDÉ, 2015b, p. 51), na parte final do conto, desnudam o movimento empreendido nas malhas literárias: mobilizar os traumas que ainda doem e repercutem, passá-los a limpo pelo viés da escrita em busca de delimitação e enfrentamento, etapas fundamentais para o processo de cura.

Certamente, "pai, mãe, ancestrais mais distantes, são então os objetos de uma pesquisa da qual, sem dúvida, uma das finalidades é que o narrador se conheça melhor por meio daquilo que herda" (VIART, 2009, p. 96). Através 
desta obra, Condé mobiliza seus ancestrais e põe em xeque as relações humanas entre brancos e negros na Guadalupe em meados do século XX. A narrativa de Condé encontra ecos no romance Ponciá Vicêncio, da escritora mineira Conceição Evaristo. A propósito, os caminhos das duas escritoras já se cruzaram em outra oportunidade. Coube à Conceição Evaristo redigir o prefácio para a reedição brasileira do romance Eu, Tituba, Feiticeira negra de Salém, de Maryse Condé, através do qual identifica "uma espécie poética da dor" (EVARISTO, 2019, p. 12) no texto da caribenha. Originalmente publicado em 1986, Moi, Tituba, sorcière noire de Salem foi o responsável pelo primeiro prêmio atribuído à escritora, o Grande prêmio literário da mulher: Prêmio Alain Boucheron, em 1987. No Brasil, o livro detém a marca de único romance antilhano de expressão francesa, até a presente data, a contar com duas traduções diferentes: a primeira, de 1997, pela editora Rocco e a segunda em 2019, pela Rosa dos Ventos, com tradução de Natália Borges Polesso. Nesta segunda publicação, o título passou a ser Eu, Tituba, Bruxa negra de Salém.

A escritora Conceição Evaristo protagonizou uma campanha inédita quando se candidatou, em 2018, por pressão popular, a uma cadeira de imortal na Academia 
Brasileira de Letras. Um abaixo-assinado na Internet reuniu em torno de de 25.000 assinaturas e a hashtag \#ConceiçãoEvaristoNaABL foi replicada à exaustão por movimentos negros, por grupos feministas e por leitores da obra da mineira. "Conceição Evaristo seria a primeira mulher negra a integrar a ABL. Não foi. Mas isso diz mais a respeito do Brasil, da Academia, e de nossa Cultura, do que sobre a autora" (AZEVEDO, 2018), afirma Dodô Azevedo no artigo de título cirúrgico "ABL não merece Conceição Evaristo". De fato, nunca se viu uma comoção de tal envergadura nas reservadas e sisudas eleição da Academia. Para além dos episódios da $A B L$, a trajetória de Evaristo depõe sobre resistências: de menina doméstica e lavadeira que cuida de oito irmãos à escritora- negra-baluarte mais importante do cenário contemporâneo, muitas águas correram para escrever sua "escrevivência". Conceição morou em comunidades, foi professora concursada da Educação básica, estreou na revista Quilombhoje com poemas, conheceu a viuvez, teve seus originais recusados inúmeras vezes por editoras (Becos da memória (2006) demorou em torno de duas décadas para ser publicado), titulou-se doutora em Literatura Comparada na Universidade Federal Fluminense, participou de Salão do Livro em Paris e foi laureada com o Prêmio Jabuti - o mais 
prestigioso prêmio brasileiro, em 2015, pela coletânea Olhos d'água.

Com Ponciá Vicêncio (2003), Conceição Evaristo realiza sua estreia romanesca. Editado originalmente por uma modesta editora de Belo Horizonte, Mazza, a obra ganhou reedições pela editora carioca Pallas. O livro conta com algumas traduções, como para o inglês e para o francês. Na obra, a autora cartografa as agruras de Ponciá, jovem sonhadora e artista do barro marcada por ausências e esvaziamentos que a tornaram, por momentos, alheia ao mundo a sua volta. O texto se organiza em capítulos curtos que, de maneira não linear, acompanham a memória da protagonista e sua relação com o passado (que reverbera no presente). A intriga confere destaque ao núcleo familiar de Ponciá, descendentes de escravizados moradores da zona rural Vila Vicêncio, no interior do Brasil. A mãe, Maria, se vê sem rumo quando os filhos rumam para a capital em busca de melhores oportunidades, o pai lavrador morre no campo durante a colheita, o irmão, Luandi José, sonha em alçar um posto de respeitabilidade na polícia e o avô se encontrava envolto a delírios e à fúria contra o rebaixamento colonial. $\mathrm{A}$ obra exibe um leque de temáticas contundentes, que lançam holofotes sobre o caráter decolonial, crítico e engajado da 
verve da escritora, como os legados da escravização, o racismo, o conflito de classes, o analfabetismo, a miséria no interior, o trabalho agrário, a (não-)maternidade e o aborto, a arte realizada pelos mais humildades, o êxodo rural, a errância, a desagregação familiar, a violência doméstica, o quotidiano das mulheres, a prostituição, a religiosidade e a vulnerabilidade nas favelas.

Nas primeiras páginas da obra, ao discorrer sobre a infância do pai de Ponciá, o narrador erige o patriarca ao lugar de "brinquedo humano", colocando-o ao encontro de Rosalie, de Anolina e de Maryse. Acompanhar uma criança do sexo masculino vilipendiado se mostra relevante para compreendermos a vulnerabilidade de toda e qualquer criança negra exposta aos desmandos (pós-)coloniais. Nestes ternos, estamos diante da "'escola da escravidão', pois desde muito cedo o filho do patriarca 'recebia' uma criança escrava, com a qual crescia, e travava uma relação para além da amizade e da companhia, pois servia como seu brinquedo" (SANTOS, 2019, p. 52). Embora a incidência da fúria dos senhores recaísse, no âmbito das brincadeiras, sobre as meninas, os meninos não passaram ilesos. Eis como a cena se inicia:

Filho de ex-escravos, crescera na fazenda levando a mesma vida dos pais. Era pajem do 
sinhô-moço. Tinha a obrigação de brincar com ele. Era o cavalo em que o mocinho galopava sonhando conhecer todas as terras do pai. Tinham a mesma idade. Um dia o coronelzinho exigiu que ele abrisse a boca, pois queria mijar dentro. O pajem abriu. A urina caía escorrendo quente por sua goela e pelo canto de sua boca. Sinhô-moço ria, ria. Ele chorava e não sabia o que mais Ihe salgava a boca, se o gosto da urina ou se o sabor de suas lágrimas. Naquela noite teve mais ódio ainda do pai. Se eram livres, por que continuavam ali? Por que, então, tantos e tantas negras na senzala? (EVARISTO, 2003, p. 17)

Tanto quanto o texto de Maryse Condé, o texto de Evaristo mostra as vísceras de uma colonização e de uma escravização que não foram abolidas por completo, afastando o destino de crianças brancas e negras. 0 narrador exemplifica esta condição:

Ponciá teve a impressão de que havia ali um pulso de ferro a segurar o tempo. Uma soberana mão que eternizava uma condição antiga. Várias vezes seus olhos bisaram uma imagem de uma mão negra rodeada de filhos. De velhas e de velhos sentados no tempo passado e presente de um sofrimento antigo. Bisaram também a cena de pequenos, crianças que, com uma enxada na mão, ajudavam a lavrar a terra. (EVARISTO, 2003, p. 49 , grifo nosso)

Desta forma, abrigados nas fazendas e trabalhando em troca de moradia e de uma pequena roça para 
autoconsumo, os ex-escravizados seguiam submetidos ao ciclo imperialista que espoliava sua mão-de-obra e sua dignidade. De maneira flagrante, reitera-se a imagem da criança-cavalo sobre a qual o senhor vai cavalgar. Observase o corpo da criança negra em posição de extrema vulnerabilidade tendo sobre as costas um(a) exitoso(a) sinhozinho(a) que sacode as pernas, se agita, faz dos cabelos da criança uma crina a ser chacoalhada. A cena traz à baila o mecanismo de "animalização" (KILOMBA, 2019, p. 79), segundo o qual "o sujeito negro torna-se a personificação do animal - a/o selvagem" (KILOMBA, 2019, p. 79). A se mencionar, igualmente, o episódio repugnante de flagrante escatologia, na qual a boca do menino negro se vê dizimada a receptáculo dos dejetos fisiológicos, o que retoma a "coisificação" proposta por Césaire.

À guisa de conclusão, narrativas afrodiaspóricas do Caribe francófono e do Brasil mostram imagens da infância de crianças negras em dois tempos complementares, tanto no período colonial quanto na contemporaneidade. À revelia da imagem amplamente divulgada de infâncias alegres cheias de potencialidades, as obras literárias contempladas descortinam infâncias trágicas marcadas por violências, perfídias e sufocamentos que golpeiam a autoestima e 
desencadeiam traumas dos pequenos. Ao retratar crianças em quotidianos abusivos, os textos colocam os miúdos no linha de frente dos mandos e desmandos (pós-)coloniais que operam as sociedades. Separadas por línguas diferentes, por diferentes décadas de publicação ao longo dos séculos $X X$ e XXI e redigidas por escritores que não necessariamente se conhecem e se leem, as narrativas analisadas neste artigo constituem, se nos valermos de termos do campo semântico cinematográfico, roteiros com o mesmo plano sequência. Trata-se de episódios reiterados nos quais um(a) sinhozinho(a) (ou seus herdeiros brancos e privilegiados) transforma a criança escravizada em "brinquedo humano", nas palavras de Eliana Alves Cruz (2018a). Rebaixadas ao mais vil lugar, estas crianças se veem aproximadas dos estágios definidos como "coisificação", por Aimé Césaire, ou "animalização", por Grada Kilomba, nos quais ocorre a destituição de seus sonhos, de sua inocência e de sua humanidade. As brincadeiras se organizam em torno de humilhações diversas que podem deslizar para ameaças, agressões físicas e, até, estupros. A lição delineada nos romances aponta para uma cisão entre a infância de crianças negras e brancas, cisão instaurada e aprofundada no período colonial, que redesenhou a natureza das relações e das oportunidades nas Américas. Comprovando que as 
braçadas coloniais pouco ou nada arrefeceram com o fim dos impérios coloniais e com a implementação da abolição da escravatura, narrativas atuais colocam em cena crianças negras vítimas de "brincadeiras", como as de outrora.

\section{Referências}

AFFONSO, Julia; MACEDO, Fausto. 'Negro em geral é catinguento, fede demais', diz Promotor de justiça de SP que afirma ter feito 'ironia'. Jornal Estadão, 2017. Disponível em: https://politica.estadao.com.br/blogs/faustomacedo/negro-em-geral-e-catinguento-fede-demais-diz-promotor-dejustica-de-sp-que-afirma-ter-feito-ironia/. Acesso em: fev. 2021.

ALMEIDA, Silvio. Racismo estrutural. São Paulo: Sueli Carneiro; Pólen livros, 2019.

AZEVEDO, Dodô. A ABL não merece Conceição Evaristo. Geledés, 2018. Disponível em: https://www.geledes.org.br/abl-nao-merece-conceicaoevaristo/?gclid=CjOKCQjw-LOEBhDCARIsABrCOTITOuQTz-gQzXcb8U00rfhRy Ql8CUHq9ylvJxrLFN3udEk Nzbh3pg8aAkfBEALw wcB. Acesso em: fev. 2021. CÉSAIRE, Aimé. Discurso sobre o colonialismo. Tradução de Claudio Willer. São Paulo: Veneta, 2020.

CHAMOISEAU, Patrick. Écrire en pays dominé. Paris: Gallimard, 2011. CHAMOISEAU, Patrick. Une enfance créole I - Antan d'enfance. Paris: Gallimard, 2015.

CHAMOISEAU, Patrick. Frères migrants. Paris: Éditions du Seuil, 2017. CHIZIANE, Paulina. O canto dos escravos. Maputo: Matiko e Arte, 2017. CONDÉ, Maryse. La parole des femmes. Paris: L’Harmattan, 2015a. CONDÉ, Maryse. Le cœur à rire et à pleurer - contes vrais de mon enfance. Paris: Robert Laffont, 2015b.

CRUZ, Eliana Alves. Água de barrela. Rio de Janeiro: Malê, 2018a. CRUZ, Eliana Alves; SEMOG, Éle; UZÊDA, André. Entrevista: Eliana Alves Cruz e Éle Semog. Revista Perspectivas em educação básica, Rio de Janeiro, 
v. 2, p. 14-28, 2018b. Disponível em: https://perspectivasemeducacao. blogspot.com/2018/11/entrevista-ele-semog-e-eliana-alves.html. Acesso em: fev. 2021.

DEMANZE, Laurent. Encres orphelines: Pierre Bergounioux, Gérard Macé, Pierre Michon. Paris: José Corti, 2008.

EVARISTO, Conceição. Ponciá Vicêncio. Belo Horizonte: Mazza edições, 2003. EVARISTO, Conceição. Prefácio - Tituba, um evocar das águas que ainda nos atormenta! In: CONDÉ, Maryse. Eu, Tituba: Bruxa negra de Salém. Tradução de Natália Borges Polesso. Rio de Janeiro: Rosa dos Tempos, p. 7-13, 2019.

FANON, Frantz. Os condenados da terra. Tradução de José Laurênio de Melo. Rio de Janeiro: Civilização Brasileira, 1968.

FANON, Frantz. Pele negra, máscaras brancas. Tradução de Renato da Silveira. Salvador: EDUFBA, 2008.

GONZALEZ, Lélia. A categoria político-cultural da amefricanidade. Tempo Brasileiro. Rio de Janeiro: Ed.Global, n. 92/93, 1988. Disponível em: https:// institutoodara.org.br/wp-content/uploads/2019/09/a-categoria-polc3adticocultural-de-amefricanidade-lelia-gonzales1.pdf. Acesso em: fev. 2021. GYSSELS, Kathleen. André Schwarz-Bart, héritage et héritiers dans la diaspora africaine. Revista Pardès, n. 44, p. 149-173, 2008.

GYSSELS, Kathleen; MENEZES, Filipe. O etno-romance de André e Simone Schwarz-Bart. Arquivo Maaravi: Revista Digital de Estudos Judaicos da UFMG, Belo Horizonte, v. 13, n. 25, p. 1-17, 2019.

JUSTIFICANDO. Promotor de SP afirma ter sido irônico ao chamar negros de "catinguentos", 2017. Disponível em: http://www.justificando. com/2017/10/03/promotor -de-sp-afirma-ter-sido-ironico-ao-chamarnegros-de-catinguentos/. Acesso em: fev. 2021.

KILOMBA, Grada. Memórias da plantação - episódios de racismo cotidiano. Tradução de Jess Oliveira. Rio de Janeiro: Cobogó, 2019. LISBOA, Vinícius. Racismo e violência contra criança e adolescente são desafios do país. Agência Brasil, 2020. Disponível em: https://agenciabrasil. 
ebc.com.br/direitos-humanos/noticia/2020-07/racismo-e-violenciacontra-crianca-e-adolescente-sao-desafio s-ao. Acesso em: fev. 2021. MARINGOLO, Cátia Cristina Bocaiuva. Água de barrela, de Eliana Alves Cruz: a saga de uma família negra no Brasil em três séculos de história. Literafro, p. 1-5, 2020. Disponível em: http://www.letras.ufmg.br/ literafro/arquivos/resenhas/prosa/ElianaCruz-Aguadebarrela. pdf. Acesso em: fev. 2021.

MEMMI, Albert. Retrato do colonizado precedido de Retrato do colonizador. Tradução de Marcelo Jacques de Moraes. Rio de Janeiro: Civilização brasileira, 2007.

PIEDADE, Vilma. Dororidade. São Paulo: Editora Nós, 2017.

SANTOS, Elisângela da Silva. "Pelos fios da memória: infância e ancestralidade em Ponciá Vicêncio". Revista Anuário de Literatura, Florianópolis, v. 24, n. 2, p. 42-58, 2019.

SCHWARZ-BART, André. A mulata solidão. Tradução de Maria João Branco. Lisboa: Cavalo de ferro editores, 2005.

SCHWARZ-BART, Simone. Un plat de porc aux bananes vertes. Paris: Éditions du Seuil, 2015.

SILVA, Maria de Jesus da. Divã de papel. Belo Horizonte: Editora Anone livros, 2013.

TAUBIRA, Christiane. L'esclavage raconté à ma fille. Paris: Philippe Rey, 2015. TEIXEIRA, Heloisa Maria. Os filhos das escravas: crianças cativas e ingênuas nas propriedades de Mariana (1850-1888). Cadernos de História, Belo Horizonte, v. 11, n. 15, p. 58-93, 2010.

VERGÈS, Françose. Le ventre des femmes - Capitalisme, racialisation, féminisme. Paris: Albin Michel, 2017.

VIART, Dominique. Le silence des pères au príncipe du "récit de filiation". Études françaises, v. 45, n. 3, p. 95-112, 2009. Disponível em: https://doi. org/10.7202/038860ar. Acesso em: fev. 2021.

VIART, Dominique. Les récits de filiation. Naissance, raisons et évolutions d'une forme littéraire. Cahiers ERTA, n. 19, p. 9-40, 2019. Disponível em: 
http://cejsh.icm. edu.pl/ cejsh/element/bwmeta1.element.ojs-doi$10 \quad 4467 \quad 23538953$ CE $19 \quad 018 \quad 11065$ ?q=bw meta1.element.ojs-issn2353-8953-year-2019-issue-19;3\&qt=CHILDREN-STATEL ESS. Acesso em: fev. 2021.

\section{Vanessa Massoni da Rocha}

Doutorado em Estudos de Literatura (possui pós-doutorado em Literatura Comparada) pela Universidade Federal Fluminense (UFF).

Professora de Língua francesa e de Literaturas francófonas na Graduação em Letras e nos programas de Pós-Graduação Lato Sensu e Stricto Sensu na Universidade Federal Fluminense.

Vice-líder do grupo de pesquisa Identidades em trânsito: estéticas transnacionais, cadastrado no CNPq.

E-mail: vanessamassonirocha@gmail.com Lattes: https://lattes.cnpq.br/2977695504057703

ORCID iD: http://orcid.org/0000-0003-2940-7931 